\title{
Agricultural Activity and Chemical Water Pollution
}

\author{
Peña BSD ${ }^{1 *}$, Barranco $\mathrm{JE}^{2}$ and Zenit $\mathrm{LM}^{2}$ \\ ${ }^{1}$ Department of Agricultural and Animal Production, Toxicology laboratory UAM-X, Mexico \\ ${ }^{2}$ Department of Biological Systems, Biotechnology laboratory UAM-X, Mexico
}

*Corresponding author: Peña BSD, Department of Agricultural and Animal Production, Toxicology laboratory UAM-X, Mexico.

Received Date: December28, 2018

Published Date: February 25, 2019

\begin{abstract}
This article reviews the water pollution by phosphate and sulfate anions, present in detergents and fertilizers; its consequences for the environment involves public health and food production. Mexican regulation for non- degradable detergents and wastewater must be updated, since in some countries these detergents are prohibited due to their negative impact on the environment.
\end{abstract}

Keywords: Water; Contamination; Phosphates; Sulphate

\section{Introduction}

Agricultural production according to the report of [1], is the main source of chemical contamination of water, due among other causes to the excessive use of fertilizers containing phosphorus, phosphates, nitrates and pesticides; also livestock activity through animal droppings whose runoff to bodies of water are another possible source of contamination with phosphorus and the use of detergents (phosphates and sulphates), within the livestock facilities.

Currently pastures for animal consumption and agricultural crops for human consumption must be produced in a sustainable and environmentally friendly manner. Such is the case of the studies carried out by Mexican researchers, whose results show that higher yields of the crops are produced with the use of bio-fertilizers.

\section{Chemical Water Pollution}

\section{The fertilizers}

The fertilizers used in agricultural production belong to the group of superphosphates, which are a source of contamination of groundwater, being dragged by rain and soil winds; since it is estimated that the crops absorb between 20 to $40 \%$ of the fertilizers applied and the rest is discarded causing water pollution, among other environmental phenomena such as acid rain and climate change. However, its use dates back to the 50's. Mexico imports about $63 \%$ of the fertilizers used in agricultural production. So the development of bio-fertilizers for some years, has been a strategy to avoid environmental damage, caused by the excessive use of chemical fertilizers. Biofertilizers contain microorganisms that live in symbiosis with plants that help them feed and protect themselves from predators [2]. The best known are the mycorrhizal fungi that provide phosphorus to the plant and Bacillus bacteria (All-Taweil et al., 2009; Pooja et al, 2007). Phosphate solubilizing microorganisms [3], such as Fusarium oxisporum, Trichoderma aureoviridae, Aspergillus aculeatus, are considered as an alternative to replace synthetic fertilizers in agricultural fields (FAO, 2008).

\section{Detergents}

Cleaning agents or detergents, are chemical products intended for the washing of machinery and inputs in the livestock industry, which are used without any restriction; However, detergents contain chemical substances such as phosphates that reduce the hardness of water, favoring the function of surfactants, which help to modify the surface tension of water and can be: zwitterionic, amphoteric, anionic, cationic and non-ionic [4].

In 1940, detergents were introduced to the world market [5], which improved the cleanliness with respect to the products that contained soap as a base; sodium tripolyphosphate being its main ingredient [6]. which represents a small portion of the phosphate market, while $85 \%$ is dedicated to the production of fertilizers [6]. Decades later he was assigned alterations in fauna in lakes with a 
high content of phosphates, because they are not compounds of easy degradation but remain for long periods of time, so the search for new compounds that are degradable mainly in developed countries, since the impact of their use such as increases in the amount of nutrients in water effluents such as rivers and lakes, the decrease in the amount of oxygen and imbalance in fish or aquatic life [6], an impact that still affects countries in Europe, Japan and the United States $[7,8]$.

In Mexico, the detergent industry represents a market of 33, 000 million pesos, it is an active industry that looks for raw materials that improve its products. Currently there are more than 400 commercial formulations whose degradation sometimes reaches $50 \%$ as in the case of sulfates (alkyl-benzene sulfonate) and a minimum degradation (10\%) for the phosphates of the alkylphenol group (nonylphenol).

It is estimated that water for agricultural use can contain up to 70,000 chemical compounds that cannot be completely eliminated in treatment plants $[9,10]$. The detergents used in dairy production facilities such as the Xochimilco dairy basin, among others, can be discharged to canals or rivers, accidentally (Casañas et al., 2015). The climate and the time of year will also influence the concentration of contaminating chemicals in surface water [8]. In traces or slaughter plants of animals that are located in semi-urban areas is another possible source of water contamination, due to the excessive use of detergents, for the cleaning of utensils, slaughter areas, eviscerated and boning of a considerable number of animals daily. Wastewater is collected through a sanitation network to be taken to a treatment plant or treatment plant. However, there is information that indicates that $40 \%$ of the aquifer that flows south of Mexico City could be contaminated with wastewater, so the chemical and microbiological contamination remains.

\section{Phosphorus, phosphates and sulphates}

The soluble phosphorus corresponds between 15 and 35\% of the total of phosphates, the polyphosphates between 65 and $85 \%$ and in smaller proportion the condensed phosphates of high molecular weight and the organic phosphates, all of them differentiated by their chemical structure, which can be ortho$\left(\mathrm{PO}_{43}{ }^{-}\right)$, meta- $\left(\mathrm{PO}_{3}{ }^{-}\right)$, para- $\left(\mathrm{P}_{2} \mathrm{O}_{74}^{-}\right)$or poly- $\left(\mathrm{PO}_{3}\right)$ n- $)$. Calcium phosphates have a dual behavior in water, because they are chemically long hydrocarbon chains at the end of which there is a cationic, anionic, amphoteric or polar group. By the number of hydrogens bound to the ionic element, mono- $\left(\mathrm{Ca}\left(\mathrm{H}_{2} \mathrm{PO}_{4}\right) 2\right)$, di$\left(\mathrm{CaHPO}_{4}\right)$, tri- $\left(\mathrm{Ca}_{3}\left(\mathrm{PO}_{4}\right) 2\right)$ and tetra- $\left(\mathrm{Ca}_{2} \mathrm{P}_{2} \mathrm{O}_{7}\right)$ are known. The main function of sodium tripolyphosphate (TPFS) is to improve the performance of detergents at low washing temperatures and with little dirt on clothes (Davidsohn \& Milwidsky, 1978). Tripolyphosphate has the following functions: a) Due to its nature, it acts on the hardness of water due to the fact that it contains salts of $\mathrm{CaCl}_{2}$ and $\mathrm{MgCl}_{2}$ that cause crystalline deposits to remain in the fabrics and, like dirt and textiles, these salts can be contained TPFS reacts with these salts and forms phosphates that do not precipitate improving the cleaning and also avoiding the deposition of crystals in the washing machine. b) Increase the surface activity of the active washing compounds due to the increase in $\mathrm{pH}$ (with a buffer) so that the ions of the dirt and fabric increase their load and therefore their repulsion, increasing the washing performance. c) Another function is the deflocculation of fragments of clay into finer particles, preventing their redeposition in clothes by wearing them down. Related to this deflocculation property, it emulsifies oily materials [6]. Phosphorus (P), is a highly reactive chemical element that has multiple uses, is widely used in the detergent industry (Casañas et al., 2015). A content greater than $0.5 \mathrm{ppm}$ of phosphates $\left(\mathrm{PO}_{4}-\mathrm{P}\right)$ causes foam, which prevents the entry of sunlight into the body of water, increasing the biological demand for oxygen (BOD) and withit problems of eutrophication, dryness of lakes and death of aquatic species [6,7]. The toxicity of phosphates even at low concentrations causes a delay in the growth of plankton, increasing the concentration of methane $\left(\mathrm{CH}_{4}\right)$ and amines in the water, because $1 \mathrm{~g}$ phosphate-phosphorus P04-P, affects the growth of 100 $\mathrm{g}$ of algae When these algae die, the decomposition processes result in a chemical oxygen demand (DCO) of around 150g, a parameter that is used to determine the quality of surface water bodies and water destined for irrigation. . Sodium pyrophosphate $\left(\mathrm{Na}_{4} \mathrm{P}_{2} \mathrm{O}_{7}\right)$ and sodium tripolyphosphate $\left(\mathrm{Na}_{5} \mathrm{P}_{3} \mathrm{O}_{10}\right)$ form stable and soluble complexes with the cations (calcium, magnesium and iron), with the disadvantage of being able to act as nutrients for some aquatic microorganisms creating an imbalance [6].

Toxicology studies have confirmed that detergents can cause eye irritation and repiratory tract, as well as alteration of the endocrine system, so the European Parliament issued a resolution on the deterrence of detergents in 2015, after having monitored more than 1000 detergents from various industries during 2012 and 2014 [9].

\section{Sulfates (S042-)}

The sulphate is a polyatomic ion with a sulfur as a central atom with four oxygen atoms around it, its chemical formula is $\mathrm{SO}_{42}{ }^{-}$. Sulfate is a surfactant, being responsible for the foam in detergents; The most common is sodium sulfate. Sulfates are salts produced by the combination of sulfuric acid with other substances, such as metals (copper sulfate).

The presence of sulfates in the water can be due to the leaching of the land, rain, or the discharge of wastewater. Most detergents contain sodium sulfonate, either straight or branched chain whose degradation is very slow, they are very abundant in nature and their content can vary, for example the concentration of iron sulphate present in the soil conditions the presence of sulfates in nearby rivers; the exploitation of pyrite in mines increases the sulfate ion in the water, mainly due to the oxidation processes that the mineral undergoes during its extraction. The alkyl-aryl sulfonates are substances obtained from aromatic compounds with an aliphatic chain attached to the aromatic nucleus. Some of the properties are their high property detergents, moisturizing power, foaming power and resistant to acids and alkalis.

The presence of sulfates in the water can be due to the leaching of the land, rain, or the discharge of wastewater. Most detergents contain sodium sulfonate, either straight or branched chain whose degradation is very slow, they are very abundant in nature and their content can vary, for example the concentration of iron sulphate 
present in the soil conditions the presence of sulfates in nearby rivers. the exploitation of pyrite in mines increases the sulfate ion in the water, mainly due to the oxidation processes that the mineral undergoes during its extraction. The alkyl-aryl sulfonates are substances obtained from aromatic compounds with an aliphatic chain attached to the aromatic nucleus. Some of the properties are their high property detergents, moisturizing power, foaming power and resistant to acids and alkalis.

Alkyl benzene sulfonate (ABS), ammonium lauryl sulfate (ammonium lauryl sulfate), ammonium lauryl ether sulfate (ammonium ether sulfate), sodium lauryl sulfate, present a high consumption worldwide that is approximately 1,500,000 a 2,000,000 tons per year (Neilsen et al, 2002), despite its low degradability and its foaming power. These substances present in wastewater passing through anaerobic treatment plants can increase their concentration and a possible risk to terrestrial fauna, since a dose of $60 \mathrm{mg} / \mathrm{kg}$ is sufficient for its toxic effect on the reproduction of invertebrate [11].

Sodium dodecylbenzene sulfonate $\left(\mathrm{C}_{12} \mathrm{H}_{25}-\mathrm{C}_{6} \mathrm{H}_{4}-\mathrm{SO}_{3} \mathrm{Na}\right)$, which according to the branches it has, can be classified as a persistent detergent (not degradable) or a biodegradable (degradable) detergent. The effect of detergents to be thrown after domestic cleaning, livestock farms and industries to lakes and rivers affected in different ways, its surfactant components cause the decrease of the solubility of oxygen in water bodies, affect the process of photosynthesis and cause lesions in the gills of the fish. Anionic surfactants, especially linear alkylbenzene sulfonates (SAL), should be of special interest since they have a special impact on aquatic and terrestrial ecosystems and are used in commercial consumer products that are discharged into wastewater after use. At concentrations of $0.02-1.0 \mathrm{mg} \mathrm{L}-1$ in fish damage the gills, causing excessive secretion of mucus, decreasing respiration, as observed in the common goby (Putschists micros), may even damage larval swimming patterns of the blue mussel (Mytilus edulis). In sludge or sediments, a concentration of $40-60 \mathrm{mg} \mathrm{SAL} \mathrm{kg-1}$ is capable of interfering with the reproduction and growth of invertebrates and earthworms. It also affects plankton and crustaceans [12].

The toxicity of the surfactant is determined by the absorption in the biological membranes and its penetration in the cell, the chemical structure of the chemical or surfactant since a hydrophilic head and a hydrophobic chain facilitates its entry, the hydrophobic part determines the ease in which it is inserted into the lipid bilayer of the cell membrane and the disturbance caused by the hydrophobic interactions once it is in the membrane causing its toxicity and causing the destruction of the function and structure of the bacterial membranes with the depolarization of the membrane, the decrease in the entry of nutrients and the excretion of substances by cellular metabolism [13].

The surfactants form heterogeneous structures consisting of two types of molecules, one with hydrophilic characteristics and the other with hydrophobic characteristics. The variation of each of them allows to improve the ability to wet, removes dirt particles that help the washing action and finally emulsifies, solubilizes and resuspends the dirt particles in the washing solution. The surfactants are classified by their ionic properties in water a) Cationic surfactants are composed of a positively charged nitrogen atom and at least one long hydrophobic chain, the most common being the quaternary ammonium compounds with a general formula $R^{\prime} R$ ' ' $R$ ' " $R$ " " $N+X$-, where generally $X$ - is a chlorine atom and $R$ represents the alkyl groups; b) Anionic surfactants such as soap contain sodium, potassium or ammonium groups, such as sodium stearate. The surfactants are classified by their ionic properties in water a) Cationic surfactants are composed of a positively charged nitrogen atom and at least one long hydrophobic chain, the most common being the quaternary ammonium compounds with a general formula $\mathrm{R}^{\prime} \mathrm{R}$ “ ' $\mathrm{R}$ ” " $\mathrm{R}$ ” “ $\mathrm{N}+\mathrm{X}$-, where generally $\mathrm{X}$ - is a chlorine atom and $\mathrm{R}$ represents the alkyl groups; b) Anionic surfactants such as soap contain sodium, potassium or ammonium groups, such as sodium stearate [14-20].

They are commonly used for their low manufacturing cost and are contained in virtually all types of detergents, the most suitable to be used are those that contain hydrophobic chains of 12-16 carbon atoms, being more degradable those that contain linear chains that branched. The most commonly used hydrophilic groups are: carboxylates $\left(\mathrm{CnH}_{2 \mathrm{n}}+1 \mathrm{COO}-\mathrm{X}+\right)$, sulfates $\left(\mathrm{CnH}_{2 \mathrm{n}}+10 \mathrm{SO}_{3}-\mathrm{X}\right.$ $+)$, phosphates $\left(\mathrm{CnH}_{2 \mathrm{n}}+10 \mathrm{PO}(\mathrm{OH}) \mathrm{O}-\mathrm{X}+\right)$ and sulfonates $\left(\mathrm{CnH}_{2 \mathrm{n}}+\right.$ $1 \mathrm{SO}_{3}-\mathrm{X}+$ ), where $\mathrm{X}+$ corresponds to $\mathrm{Na}$, $\mathrm{K}_{\text {or }} \mathrm{NH}_{4}$. These detergents are very effective for the removal of oily particles. However, these detergents require other ingredients such as phosphates to prevent their deactivation by ions such as $\mathrm{Ca}_{2+}$ and $\mathrm{Mg}_{2+}$ that correspond to the hardness of the water.C) Non-ionic surfactants, prevent deactivation by water hardness and remove oily particles by solubilization and emulsification, are generally contained in liquid detergents and are sometimes mixed with anionic, are termed alcohol surfactants and ethoxylated alkylphenols. Another type of nonionic surfactants are the alkyd polyglycolides D) Amphoteric surfactants containing both anionic and cationic groups and are known as alkyl dimethyl betaine. Its cleaning function depends on the $\mathrm{pH}$ of the water solution, at acidic $\mathrm{pHs}$ it acts as a cationic surfactant and at alkaline $\mathrm{pH}$ as an anionic surfactant, its solubility depends on its isoelectric point and forms mixed micelles with other types of surfactants [9].

\section{Conclusion}

The chemical contamination of water causes an alteration in its composition, temperature, acidity and eutrophication. The signs of an eutrophication are: increase in algae aquatic plants, replacement of desirable fish by other unwanted species, production of toxins by certain algae, unpleasant odor, decrease in oxygen and fish mortality. The sanitary, chemical and toxicological safety of the residual water must be a requirement for its reuse since the sanitation processes are not designed to eliminate chemical substances or pathogenic microorganisms in their entirety, so it is necessary to implement innovative strategies in the municipal network of sewerage. In addition to including periodic monitoring plans, depending on their location and use, to strengthen environmental management programs in order to predict a possible risk. It is important to comply with the regulatory framework of chemical substances in reusable water for agricultural and livestock activities, which 
requires sensitive analytical techniques that ensure their results. The population should be made aware of not spilling wastewater in the water channels as well as the use of biodegradable detergents ( $<15 \%$ phosphates), in order to avoid damage to public health and the environment.

\section{Acknowledgement}

None.

\section{Conflicts of Interest}

No conflicts of interest.

\section{References}

1. FAO (2012) Perspectivas para el medio ambiente, Agricultura y medio ambiente.

2. García VRR (2003) Nuevo siglo, nuevos riesgos sanitarios y ambientales en el agua. Rev Salud Amb 3(2): 77-85.

3. Lugtenberg B, Kamilova F (2009) Plant-Growth-Promoting rhizobacteria. Ann Rev Microbiol 63: 541-556.

4. Campuzano S, Camacho JE, Alvarez A (2006) Caracterización del desecho tóxico producido en PYMES que fabrican detergentes. Gestión y Ambiente 9(1).

5. Kogawa AC, Gamberini Cernic B, Domingos do Couto LG, NunesSalgado HR (2017) Synthetic detergents: 100 years of history. Saudi Pharmaceutical Journal 25(6): 934-938.s

6. Khöler J 2006. Detergent phosphates: an EU policy assessment. Journal of Bussines Chemistry 3(2): 15-30.

7. Farmer A (2004) Phosphate pollution: a global overview of the problem. In Phosphorus in environmental technologies: principles and applications. E Valsami Jones (eds) London IWA, UK, pp. 174-191.

8. Goel G, Kaur S (2012) A study on chemical contamination of water due to household laundry detergents. Journal of Human Ecology 38: 65-69.
9. Bajpai D, Tyagi VK (2007) Laundry detergents: an overview. Journal of Oleo Science 56(7): 327-340.

10. González, B (2004) Jabones y detergentes. Impacto ambiental. Universidad Autónoma de México disponible

11. Mungray AK, Kumar P (2009) Fate of linear alkylbenzene sulfonates in the environment: A review. International Biodeterioration and Biodegradation 63: 981-987.

12. Venhuis SH, Mehvar M (2004) Health effects, environmental impacts, and photochemical degradation of selected surfactants in water. International Journal of Photoenergy 6: 115-125.

13. Cowan- Ellsberry C, Belanger S, Dorn P, Dyer S, McAvoy D, et al. (2014) Environmental safety of the use of major surfactant classes in North America. Critical Reviews in Environmental Science and Technology 44(17): 1893-1993.

14. Aloui F, Kchaou S, Sayadi S (2009) Physicochemical treatments of anionic surfactants wastewater: Effect on aerobic biodegradability. Journal of Hazardous Materials 164(1): 353-359.

15. Benito M, Laplante D, Fernández MT, Miguel N (2018) Amebas de vida libre en aguas residuales y fangos. Rev Salud Ambiental 18(1): 69-77.

16. Carpio, Milenia (2006) Fósforo total en agua por digestión ácida. Instituto de hidrología, Meteorología y Estudios ambientales.

17. NOM (1996). Límites máximos de contaminantes en aguas residuales.

18. Olea SN, Fernández CMF, Olmedo MP (2001) Rev Salud Ambiental 1(2): 64-72.

19. Roa PAL, Cañozares VRO (2012) Bioremediación de aguas con fosfatos y nitratos utilizando Scenedesmus incrassatulus inmovilizado en alginato de calcio. Bistua 10(1):71-79.

20. Secretaría de Comercio Fomento industrial CFI (2001a). Norma Oficial Mexicana C. Análisis de agua -Determinación de la demanda química de oxígeno en aguas naturales, residuales y residuales tratadas. México, DF: Secretaría de Comercio y Fomento industrial. Secretaría de Comercio y Fomento industrial, SCFI. (2001b). 